\title{
19: 10375271-10362809
}

National Cancer Institute

\section{Source}

National Cancer Institute. 19: 10375271-10362809. NCI Thesaurus. Code C41919.

Physical location of CDC37_Gene 